\title{
MINING
}

UDC 622.831.24.001

O. Ye. Khomenko, Dr. Sc. (Tech.), Prof., orcid.org/0000-0001-7498-8494,

M. M. Kononenko, Cand. Sc. (Tech.), Assoc. Prof., orcid.org/0000-0002-1439-1183

\section{GEO-ENERGETICS OF UKRAINIAN CRYSTALLINE SHIELD}

Purpose. To develop an analytical method which allows investigating the energy condition of rocks within the Ukrainian Crystalline shield.

Methodology. Analytical research on the energy condition of rocks has been conducted by means of a new method of research - the entropy one. The research on processes of redistribution of potential energy in the massif of rocks was conducted by analogy with an open thermodynamic system. The accepted methodological approach allowed investigating processes of energy exchange in rocks and natural transformations of some types of energy to others.

Findings. The analysis is conducted and systematization of geodynamic conditions by underground mining of ore fields of Ukraine is executed. The ways of development of new hypotheses, theories and methods of research of the energy condition of rocks are given. The description perspective in world practice of a natural condition of rocks is enclosed. Components of redistribution of energy in the massif of rocks are defined: entropy, potential stresses and angles of their action. An inspection of the results obtained on convergence is conducted and corresponding conclusions on their application are drawn.

Originality. The thermodynamic balance in rocks of the Ukrainian Crystalline shield is formed due to equilibration of vertical and horizontal power streams which, with increasing mining depth, enhance components of a tensor of stress on sedate dependence, rejecting them from hydrostatic ones during increasing in mining depth.

Practical value. The entropy method of research which allows investigating natural state of rocks with increasing depth is developed. Classification of methods of research on the stress-strain state of rocks due to introduction of a synergetic group which includes entropy, thermodynamic and energy methods is improved. It is established that distribution of entropy in rocks of the Ukrainian Crystalline shield proceeds in mutually perpendicular directions, which correspond to vertical and horizontal energy streams.

Keywords: rock massif, rock pressure, underground mining, geodynamic phenomena, energy state, synergetic methods, potential stress, reversible deformations

Introduction. The long-term observations of rocks behavior in the process of deepening in subsoil have confirmed that the amount of elastic potential energy grows in massifs with increasing in depth. Strong elastic rocks accumulate much more potential energy than weak ones in which with a growth in pressure, plastic deformations are actively shown. The bigger released energy is, the more dynamically processes of rock deformation proceed and, it is heavier than their consequences. During rock bumps, the release of rocks from stress is followed by instant transition of potential energy to work with seismic effect and airburst [1]. Therefore, for instance, during 135 years of active development of ore deposits in Ukraine, depths of mining operations have reached a point of $1500 \mathrm{~m}$ that has led to considerable deterioration in geodynamic conditions [2, 3]. Elastic potential energy of the Ukrainian crystal board has be-

(C) Khomenko O. Ye., Kononenko M. M., 2019 gun to be shown not only in the form of peelings and roof-rock slip formations, and in the form of bursting, rock bumps and regular earthquakes of various amplitude. It has led to loss of mine workings and reserves of minerals, damage of objects on a surface and in subsoil and, unfortunately, to traumatizing and death of people. Therefore, essential increase in efficiency and volumes of extraction of ore raw materials in our country is impossible without disclosure and the description of processes and regularities of management of natural factors and their application in geo-energetic technologies of mining of deposits in Ukraine [4].

The assessment of rock-bump hazard in mine deposits of Kryvorizskyi Iron-ore Basin at depths up to $2000 \mathrm{~m}$ was determined by value of coefficient of dynamism of the deformation process of the massif with transformation of potential energy to work. It represents the relation of dynamic loading from the volume density of energy in the undisturbed massif of rocks $W \sigma$ to stress and is caused 
by static action of the same loading $\sigma_{\text {comp }}$ as a result of destruction of a unit of rock volume, $K w=W \sigma / \sigma_{\text {comp }}$, where, $\mathrm{kJ} / \mathrm{cu}$. $\mathrm{m}$ for mines of Kryvbas. Such event is more often shown not in the form of peeling of rocks (up to $900 \mathrm{~m})$, but the massif's roof-rock slip (1000-2000 m), and in the form of rock burst (1600 $\mathrm{m}$ and more) and rock bumps (more than $2100 \mathrm{~m}$ ) (Table 1) [4, 5].

There is still an open question about the cause of more intensive development of rock pressure manifestations in granites in the form of peeling and roof-rock slip formation at depths of 900-1100 m. While in amfibolithe with the same strength and elastic characteristics of the similar phenomena, it is not noted even at depths of 1400-1600 m [6]. Therefore, geodynamic manifestations of rock pressure, rock bursting sand microblows in ore mines of Ukraine will take place at depths of over 1600-1700 m, which today mines of Kryvbas are approaching with capital mining operations, and effective technologies of account and application of this energy have been offered by authors only in recent years.

Scientific problem. Stress-strain state (SSS) of the untouched massif of rocks is examined in various re- gions of the world by unloading, hydraulic fracturing and seismic-acoustic methods. Over 130 thousand measurements in 150 types of rocks have shown that stresses which are connected with deformations do not match the developed idea that vertical stress component $\sigma z=$ $=\gamma H$, where $\gamma$ is the volume mass of rock; $H$ is depth, has to be more than horizontal component $\sigma x=\sigma y=K \sigma z$ where $K<1$ is the coefficient of a side thrust [7]. Horizontal stresses according to measurements have appeared much more vertical, which should not have been. The generalized results of measurement of stresses in rock massifs of Scandinavia, South Africa, Ireland, Iceland, Spitsbergen island, Zambia, Canada, the USA, and Australia have shown that vertical stresses increase in proportion to depth, differ a little bit among themselves in various parts of the Earth. Also they are characterized by the straightforward diagrams that appear almost from zero point. Horizontal stresses depending on depth in various parts of the earth's sphere are not identical and also on an absolute value more than vertical ones. In the territory of the Canadian Shield, the prevalence of horizontal stresses over vertical is observed.

Table 1

Geodynamic conditions of ore mines of Ukraine

\begin{tabular}{|c|c|c|c|c|c|}
\hline \multirow[t]{2}{*}{ Enterprise } & \multirow[t]{2}{*}{ Mine } & \multirow{2}{*}{$\begin{array}{l}\text { Mining } \\
\text { depth, } \\
H, \mathrm{~m}\end{array}$} & \multirow{2}{*}{$\begin{array}{l}\text { Coef. of } \\
\text { impact, } \\
K_{W}\end{array}$} & \multicolumn{2}{|c|}{$\begin{array}{c}\text { Type of rock } \\
\text { pressure manifestation }\end{array}$} \\
\hline & & & & Granites & Amphibolite \\
\hline \multicolumn{6}{|c|}{ Preparatory, stoping and backfilling operations } \\
\hline PJSC “MIOP” & $\# 3-5,7,8,9-10,14-15$ & 100 & 0.025 & \multicolumn{2}{|c|}{ Convergence } \\
\hline SE "ShidIOP" & \multirow{4}{*}{$\begin{array}{l}\text { "Novokostiantynivska" } \\
\text { "Smolinska" } \\
\text { "Inhulska" }\end{array}$} & 200 & 0.05 & \multirow{8}{*}{\multicolumn{2}{|c|}{$\begin{array}{c}\text { Peeling } \\
(0.4-63.0 \mathrm{~J})\end{array}$}} \\
\hline \multirow[t]{4}{*}{ LLC "Shid-Ruda" } & & 300 & 0.06 & & \\
\hline & & 400 & 0.09 & & \\
\hline & & 500 & 0.11 & & \\
\hline & "Nova" & 600 & 0.15 & & \\
\hline \multirow[t]{2}{*}{ PJSC “ZZhRK” } & \multirow{2}{*}{$\begin{array}{l}\text { "Ekspluatatsiina" } \\
\text { "Prohidnycha" }\end{array}$} & 700 & 0.19 & & \\
\hline & & 800 & 0.23 & & \\
\hline PJSC “AM Kryvyi Rih” & "n.a. Artem" & 900 & 0.27 & & \\
\hline \multirow[t]{2}{*}{ PJSC "Sukha Balka” } & \multirow{2}{*}{$\begin{array}{l}\text { "n.a. Frunze" } \\
\text { "Yuvileina" }\end{array}$} & 1000 & 0.31 & \multirow{6}{*}{\multicolumn{2}{|c|}{$\begin{array}{l}\text { Roof-rock slip } \\
\left(64.0-2 \cdot 10^{2} \mathrm{~J}\right)\end{array}$}} \\
\hline & & 1100 & 0.35 & & \\
\hline \multirow[t]{4}{*}{ PJSC “KZhRK” } & \multirow{4}{*}{$\begin{array}{l}\text { "Zhovtneva" } \\
\text { "Hvardiiska" } \\
\text { "Ternivska" } \\
\text { "Batkivshhina" }\end{array}$} & 1200 & 0.42 & & \\
\hline & & 1300 & 0.49 & & \\
\hline & & 1400 & 0.57 & & \\
\hline & & 1500 & 0.68 & & \\
\hline \multicolumn{6}{|c|}{ Capital mining operations } \\
\hline \multirow{6}{*}{$\begin{array}{l}\text { PJSC "AM Kryvyi Rih" } \\
\text { PJSC "KZhRK" } \\
\text { PJSC "Sukha Balka" }\end{array}$} & \multirow{6}{*}{$\begin{array}{l}\text { "n.a. Artem" } \\
\text { "Batkivshhina" } \\
\text { "Zhovtneva" } \\
\text { "Yuvileina" } \\
\text { "Hvardiiska" } \\
\text { "Ternivska" }\end{array}$} & 1600 & 0.83 & \multirow{5}{*}{$\begin{array}{c}\text { Bursting } \\
\left(2 \cdot 10^{3}-2 \cdot 10^{6} \mathrm{~J}\right)\end{array}$} & \multirow{5}{*}{$\begin{array}{l}\text { Roof-rock slip } \\
\left(64.0-2 \cdot 10^{2} \mathrm{~J}\right)\end{array}$} \\
\hline & & 1700 & 0.98 & & \\
\hline & & 1800 & 1.15 & & \\
\hline & & 1900 & 1.32 & & \\
\hline & & 2000 & 1.49 & & \\
\hline & & 2100 & 1.66 & $\begin{array}{c}\text { Rock bumps } \\
\left(6.3 \cdot 10^{7} \mathrm{~J}\right)\end{array}$ & $\begin{array}{c}\text { Bursting } \\
\left(2 \cdot 10^{3}-2 \cdot 10^{6} \mathrm{~J}\right)\end{array}$ \\
\hline
\end{tabular}


Contradictory results on the territory of North America during measurement of stresses in wells up to $5 \mathrm{~km}$ in depth were obtained by methods of seismic-acoustic and hydraulic fracturing. Even more contradictory values of vertical stresses were received in the well at depths up to $5325 \mathrm{~m}$ in the State of Michigan, the USA by the hydraulic fracturing method, which showed that the actual value of vertical stresses is up to $40 \%$ less than the corresponding value $\gamma H$ [8]. Measurements of vertical stress by the seismic-acoustic method on the deep well of the Kola Peninsula, Russia also confirmed that $\sigma z<$ $<\gamma H$ by $40-50 \%$ [9]. Then, the hypothesis of recession of a vertical component of gravitational pressure with increase in depth was suggested. Therefore, until the present time not only approved methods of research on natural energy state of rock massifs have not been developed, but adequate methodological approaches to its definition have not even been offered [10].

Research methods. Despite variety of the applied methods and diagnostic aids, and control of stress-strain state of the massif, they can be united in three classes based on functional purpose: natural (industrial), physical (laboratory) and analytical (theoretical), whereas classes are subdivided into groups (visual, sur-veying, mechanical, geophysical, etc.) and further into types. Application of the sign "a way of representation of the massif" classification in the form of Table 2 [11] has been composed.

Perfect level of research on physical properties of rocks has to be characterized by synergetic methods (approaches, hypotheses, theories). Synergetic methods can investigate processes of energy exchange in the mineral environment and natural transformations of one type of energy to others, examination of properties of the interacting open systems by the analysis of the conditions and quantitative ratios arising with transformation of energy [12]. The main advantages of synergetic methods are: the high degree of universality that allows describing mechanisms of emergence of energy fields in crust, essence of processes of heat exchange, transformation of potential energy of elastic deformation to work, processes of redistribution and arising of stresses surrounding mine working in the massif, accumulation of violations and the nature of destruction of the massif [13].

For creation of the energy theory which adequately describes the phenomenon of zonal capsulation of mine workings, it is possible during application of synergetic methods of research: entropy, thermodynamic, energetic. The thermodynamic method was created by V.F. Lavrinenko, approved and is widely applied in modeling. V. F. Lavrinenko also laid the foundation for the entropy method within the thermodynamic theory [14]. For creation of the entropy method, a part of the thermodynamic theory was finished and expanded for its application as an isolated research method. Further, on the basis of the entropy method, which determines parameters of the undisturbed massif of rocks, and the thermodynamic method, which models a condition of the massif in near-the-contour zone (unloading zone) of mine workings, one more method has also been developed, a synergetic method, which is the energetic method. It allows modeling a condition of the massif in energy zones which form the safety capsule around mine working and describing interaction of mechanical, thermodynamic and other types of energies [15].

Entropy Method. Model of energy redistribution in the undisturbed massif. According to the second law, unequal values of any of intensity factors (stress, temperature, density, magnetization, etc.) in various parts of the system cause origination of the irreversible spontaneous thermodynamic process leading to their alignment and establishment of corresponding mechanical thermal, density and other types of balance. Driving force of the process is the difference of energy components: stresses, temperatures, the volume density or other factors of intensity that do not depend on the mass of the system [16-18]. The directions of course of these processes are caused by the directions of action of external entropy $d_{e} S$ on the open system presented by mineral substance of crust which acts in the vertical plane (Fig. 1, b) [19]. In-

Table 2

Classification of research methods on rocks condition

\begin{tabular}{|c|c|c|}
\hline Class & Group & Type \\
\hline \multirow{4}{*}{$\begin{array}{l}\text { I. Natural } \\
\text { (industrial) }\end{array}$} & Visual & Observations and estimations \\
\hline & Surveying & Mine surveying \\
\hline & Mechanical & $\begin{array}{l}\text { Unloadings of the massif, compensation loading, difference ofpressure, elastic } \\
\text { inclusions, deformations of wells, deep reference points }\end{array}$ \\
\hline & Geophysical & Acoustic, ultrasonic, radiometric, electrometric, geomagnetic \\
\hline \multirow{4}{*}{$\begin{array}{l}\text { II. Physical } \\
\text { (laboratory) }\end{array}$} & Research on rock properties & Density, mechanical \\
\hline & Equivalent materials & Modeling on pressure machines, centrifugal testing of models \\
\hline & Optical polarization & $\begin{array}{l}\text { Modeling on pressure machines, centrifugal testing of models, three-dimensional } \\
\text { photoelasticity }\end{array}$ \\
\hline & Electrodynamic analogy & Electric grids, conductive materials \\
\hline \multirow[t]{2}{*}{$\begin{array}{l}\text { III. Analytical } \\
\text { (theoretical) }\end{array}$} & Rock mechanics & $\begin{array}{l}\text { Continuous environment, elasticity, plasticity, creep, boundary differences, } \\
\text { boundary elements, finite elements }\end{array}$ \\
\hline & Synergetic & Entropy, thermodynamic, energy \\
\hline
\end{tabular}



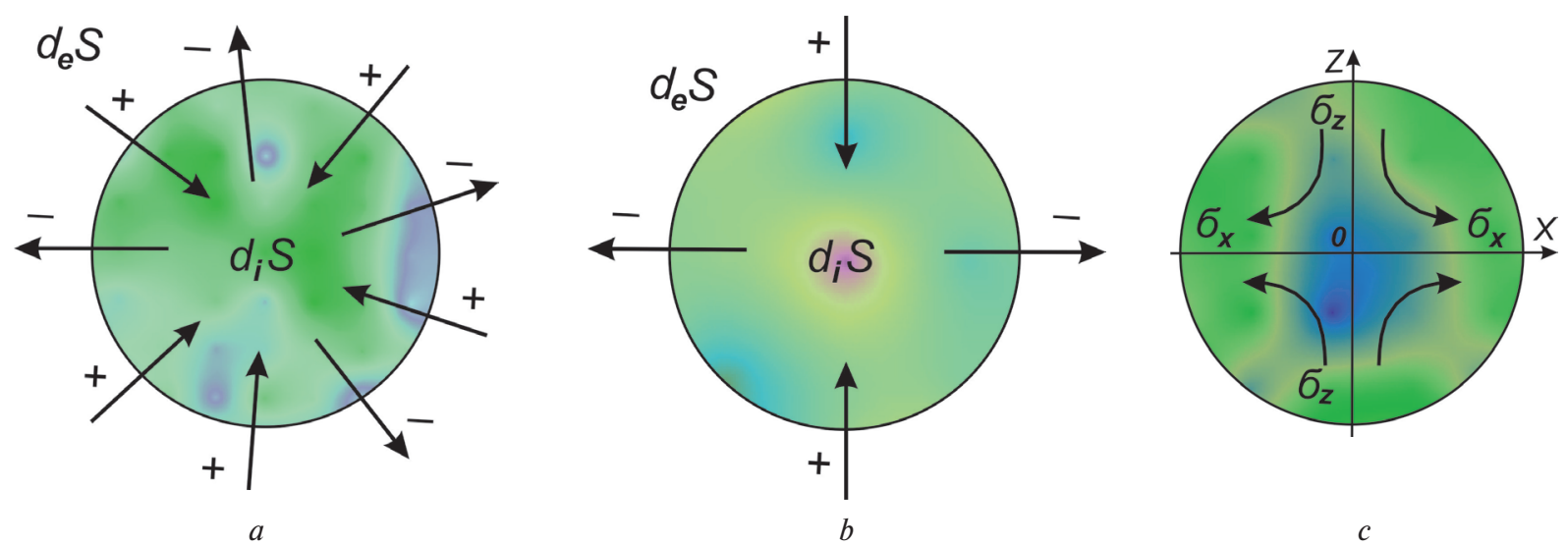

Fig. 1. Exchange of entropy between the system and the external environment (a), establishment of spontaneous thermodynamic balance (b) and course of process of potential energy redistribution in thermodynamic system (c)

equality of volume density of potential energy in thermodynamic system is the cause of the spontaneous process providing its redistribution and establishment of thermodynamic balance in the massif. A distinctive feature of any irreversible process is increase in entropy, the function of a state characterizing the direction of course of spontaneous processes in the thermodynamic system that is not exchanging weight with the external environment. According to the law of increase in entropy at achievement of equilibrium state, the entropy of the system becomes maximum [20].

Changing of entropy from action of external forces will meet a condition for a circle of external stresses

$$
d_{e} S=S_{e(x)}-S_{e(z)}>0 .
$$

At the same time, the entropy in the vertical and horizontal planes is of the form of (Fig. 1,c)

$$
S_{e(z)}=\frac{\delta W_{\sigma}}{\sigma_{z}} ; \quad S_{e(x)}=\frac{\delta W_{\sigma}}{\sigma_{x}},
$$

where $\delta W_{\sigma}$ is an infinite small quantity of energy.

The flow of potential energy can pass only from stresses scope $\sigma_{z}$ where the volume density of energy is higher, into action of stress $\sigma_{x}$, where the volume density of energy is lower. In the opposite direction, the course of spontaneous process is impossible to occur as it contradicts the second law of thermodynamics $\left(d_{e} S\right.$ can't be $<0$ ). The main external energy source is force of gravitation that is directed on a normal to the center of the Earth and is described by the law of universal gravitation. A distinctive feature of gravitational field is that the material system placed in it is affected by the gravity directly proportional to the mass of this system [21]. According to the first law of thermodynamics, the law of energy conservation, the area of an ellipse with an uneven volume density of potential energy is $S_{e l}=\pi a b$, (where $a=\sigma_{z}$ and $b=\sigma_{x}$ ), the equal area of a circle is $S_{c}=\pi R_{e}$ within which the energy is distributed evenly. The radius of a circle is equal to stresses size corresponding to balance condition in the system

$$
R_{e}=\sigma_{z} \lambda^{0.5} \text {. }
$$

The increments of vertical and horizontal stresses are

$$
\begin{aligned}
& \Delta \sigma_{z}=\sigma_{z}-R_{e}=\sigma_{z}\left(1-\lambda^{0.5}\right) ; \\
& \Delta \sigma_{x}=R_{e}-\sigma_{x}=\sigma_{z}\left(\lambda^{0.5}-1\right) .
\end{aligned}
$$

Correlation $\frac{\Delta \sigma_{z}}{\Delta \sigma_{x}}>1$, at $0 \leq \lambda \leq 1$ (Table 3).

The number of increments of external stresses has a view

$$
\Delta \sigma_{z}+\Delta \sigma_{x}=\sigma_{z}+\sigma_{x}
$$

It means that in the system only the part of potential energy created by means of the difference of external stresses is redistributed.

$$
\Delta W_{\sigma}=0.5 E^{-1}\left(\sigma_{z}^{2}-\sigma_{x}^{2}\right)
$$

Distribution of entropy in the open system exchanging with the external environment energy and substance can proceed in any directions. Exchange of entropy in the system presented by the mineral environment in the form of rocks proceeds in mutually perpendicular directions corresponding to the vertical and horizontal energy flows operating in rocks of Prydniprovsky geoblock with the durability up to $140 \mathrm{MPa}$ and at depths up to $1500 \mathrm{~m}$ (Table 3) [22].

Establishment of spontaneous energy balance leads to redistribution of entropy in the elementary thermodynamic system presented by the massif of rocks. So, with a vertical pressure of $50 \mathrm{MPa}$ at a depth of $1500 \mathrm{~m}$ in the massif only a part of the potential energy is created by means of the difference of external stresses whose volume is equal to 50 for the horizontal stresses, and $45 \%$ for vertical is redistributed [23].

Redistribution of energy in thermodynamic system. Thermodynamic potentials maintain from the outside of value temperatures and the volume of any open system. The system evolves in such conditions to the condition of balance characterized by presence of thermodynamic potential. The condition of balance is the transformation purpose for nonequilibrium conditions of systems that truly was noticed still by M. Planck. For expansion of the field of applicability of thermodynamics so that it could also be used in the analysis of nonequilibrium processes, we need the exact formula which allows calculating production of entropy. Progress in 
Components of redistribution of energy in the mineral environment corresponding to physical properties of the Prydniprovsky geoblock

\begin{tabular}{|c|c|c|c|c|}
\hline \multirow{2}{*}{$\begin{array}{c}\text { Vertical pressure, } \\
\sigma_{z}, \mathrm{MPa}\end{array}$} & \multirow{2}{*}{$\begin{array}{c}\text { Coefficient of ellipse } \\
\text { form of stresses, } \\
a / b=\lambda\end{array}$} & \multirow{2}{*}{$\begin{array}{l}\text { Radius of a circle of } \\
\text { internal stresses, } \\
\qquad R_{e}, \mathrm{~m}\end{array}$} & \multicolumn{2}{|c|}{ External stresses, $\mathrm{MPa}$} \\
\hline & & & horizontal $\Delta \sigma_{x}=\Delta \sigma_{y}$ & vertical $\Delta \sigma_{z}$ \\
\hline 0 & 1.00 & 0 & 0 & 0 \\
\hline 10.0 & 0.97 & 5.07 & 5.07 & 4.93 \\
\hline 20.0 & 0.94 & 10.28 & 10.28 & 9.72 \\
\hline 30.0 & 0.91 & 15.64 & 15.64 & 14.36 \\
\hline 40.0 & 0.88 & 21.20 & 21.20 & 18.20 \\
\hline 50.0 & 0.85 & 24.04 & 24.04 & 20.96 \\
\hline
\end{tabular}

this direction has been made during assumption according to which and out of balance of system $S$ depends only on the same variables on which it depends when the system is in a condition of balance - assumption about existence of the integrated balance [24] was accepted. Having accepted this assumption, we re-ceive expression for $P$ - productions of entropy system in unit of time

$$
P=\frac{d_{i} S}{d t}=\sum_{p} J_{p} X_{p} \geq 0
$$

where $J_{p}$ is speeds proceeding in the considered system of various irreversible processes (entropy, thermal streams, chemical reactions); $X_{p}$ is the corresponding generalized forces (gradients of stresses temperature, chemical and geostatic potentials). The equation (5) is the main expression of thermodynamics of irreversible processes of macroscopic systems. When the system is in a condition of thermodynamic balance, for all reversible processes of proceeding in it $J_{p}=0$ and $X_{p}=0$. Therefore, it is quite natural to assume that near a condition of balance linear uniform ratios between flows of energy and forces (stresses) causing them take place. Interaction with the external environment causes changes in the system (Fig. 2, b). External stresses interact with internal, holding adjacent particles in knots of a crystal lattice at the corresponding equilibrium distances. Internal stresses for the solid body that is in a free state are also equal to an elasticity limit $\sigma_{e l}[25,26]$.

At external power impact on the elementary volume of rock, there is a positive difference of internal residual stresses in the horizontal and vertical planes [27]

$$
\begin{gathered}
\left(\sigma_{e l}-\sigma_{x}\right)>\left(\sigma_{e l}-\sigma_{z}\right) ; \\
\left(\sigma_{e l}-\sigma_{x}\right)-\left(\sigma_{e l}-\sigma_{z}\right)>0 .
\end{gathered}
$$

The volume density of potential energy from action of residual internal stresses in two parts of system is not

$$
\text { identical } \begin{aligned}
\frac{W_{\sigma_{z}}}{W_{\sigma_{x}}}<1 \\
W_{\sigma_{z}}=0.5\left(\sigma_{o ́ t}-\sigma\right)^{2} E^{-1} ; \\
W_{\sigma_{x}}=0.5\left(\sigma_{e l}-\sigma_{x}\right)^{2} E^{-1} .
\end{aligned}
$$

Changes in entropy in the system during the spontaneous irreversible process leading to alignment of stresses and uniform distribution of potential energy are described by a formula

$$
\delta S_{i}=\delta W_{\sigma}\left[\left(\sigma_{e l}-\sigma_{z}\right)^{-1}-\left(\sigma_{e l}-\sigma_{x}\right)^{-1}\right]>0 .
$$

Inside the system, energy flows from areas with higher density in the field of lower, i.e. from the horizontal
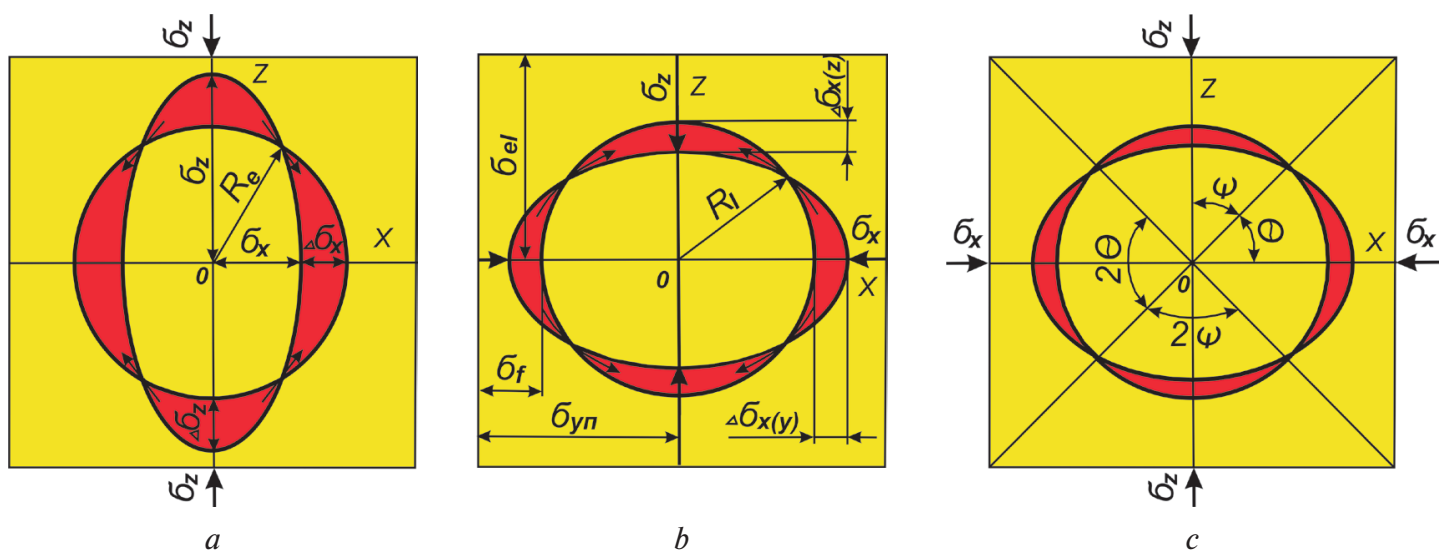

Fig. 2. Redistribution of potential energy in the thermodynamic system (a), formation in its elastic potential stresses (b) and the angles of action of the main normal stresses in the elementary volume of rock (c) 
plane to the vertical one arise [28]. If to designate coefficient of residual elasticity as

$$
\lambda_{e l . o}=\left(\sigma_{e l}-\sigma_{z}\right)\left(\sigma_{e l}-\sigma_{x}\right)^{-1},
$$

so, the coefficient characterizing extent of plastic properties of system changing will be equal to $\lambda_{p}=-\lambda_{\text {el. } .}$.

The radius of a circle of internal stresses corresponding to mechanical balance of the system also has a view of (Fig. 2, b), m

$$
R_{i}=\left(\sigma_{e l}-\sigma_{x}\right) \lambda_{e l . o}^{0.5}
$$

During internal stress of $R_{i}$ formation of entropy reduces to 0 , and the entropy of the system reaches the maximum value [29].

Increments of stresses inside the system correspond to (Table 3), MPa

$$
\begin{aligned}
& \Delta \sigma_{z(y)}=R_{i}-\left(\sigma_{e l}-\sigma_{x}\right) ; \\
& \Delta \sigma_{x(y)}=\left(\sigma_{e l}-\sigma_{x}\right)-R_{i} .
\end{aligned}
$$

The number of increments will have a view of, $\mathrm{MPa}$

$$
\Delta \sigma_{z(y)}+\Delta \sigma_{x(y)}=\sigma_{z}-\sigma_{x},
$$

and the relation of vertical stresses to horizontal ones will be less than 1

$$
\frac{\Delta \sigma_{z(y)}}{\Delta \sigma_{x(y)}}<1
$$

at $0<\lambda_{\text {el.o }}<1$.

The actual external stresses actting on the thermodynamic system are equal on absolute value, $\mathrm{MPa}$

$$
\begin{aligned}
& \sigma_{z f}=\sigma_{z}-\Delta \sigma_{z(y)} ; \\
& \sigma_{x f}=\sigma_{x}+\Delta \sigma_{x(y)} .
\end{aligned}
$$

The elastic stresses connected with deformations are potential because their work depends on the size of the reversible deformation arising at partial or full removal of external loading [30]. Because of increments of potential energy in rocks of the Ukrainian Crystalline Shield, only its part participates in deformation processes. Increase in vertical pressure up to $91 \mathrm{MPa}$ at a depth up to $3000 \mathrm{~m}$ leads to redistribution of potential energy in the massif, which is equal to $57 \%$ for vertical elastic potential stresses and $95 \%$ for horizontal ones (Table 4).
Equilibration of reversible deformations in thermodynamic system. The origination of a positive difference of residual stresses in two mutually perpendicular parts of the system leads to an entropy increment in the system and promotes uniform distribution of potential energy in the system. In such conditions, the conservation law of mass $m=\rho_{o} V_{o}=\rho_{i} V_{i}=$ const is satisfied: the mass of the isolated system does not change during any processes happening in it; where $\rho_{o}$ and $\rho_{i}$ are the initial and changed density, $V_{o}$ and $V_{i}$ are the initial and changed body volumes. In relation to the mineral environment of rocks, it is possible to determine the value of the isothermal coefficient of consolidation of substance at a required depth of $K_{y}=V_{o} V_{i}^{-1}=\rho_{i} \rho_{o}^{-1}$. The basis for definition of the intense deformed condition of the massif and volume density of potential energy in it is Hooke's law: $\sigma=\varepsilon \cdot E$ or $\sigma=\Delta V \cdot K$, which describes interrelation between stress $\sigma$ and deformation $(\varepsilon-$ linear, $\Delta V$ - volume).

According to Duhamel-Neumann's theory, in the undisturbed massif of rocks during existence of the temperature field, elastic-plastic deformation of rocks occurs [31]. The general linear deformation $\varepsilon_{o}$ edges of a cube in which the thermodynamic system is concluded, consists of elastic $\varepsilon_{e l}$ and inelastic (plastic) $\varepsilon_{p}$ components, i. e $\varepsilon_{o}=\varepsilon_{e l}+\varepsilon_{n}$. At the same time, elastic deformations are defined as

$$
\begin{gathered}
\varepsilon_{\hat{\imath}}=1-K_{s}^{-0.33} ; \quad \varepsilon_{z(y)}=\Delta \sigma_{z(y)} E^{-1} ; \\
\varepsilon_{x(y)}=\varepsilon_{y(y)}=\Delta \sigma_{x(y)} E^{-} .
\end{gathered}
$$

Plastic deformations $\varepsilon_{z(p)}=\varepsilon_{0}-\varepsilon_{z(y)} ; \varepsilon_{x(p)}=\varepsilon_{y(p)}=\varepsilon_{0}-$ $-\varepsilon_{x(y)}$ are caused by increasing temperature of rock in the process of thermodynamic system deformation that happens with increase in depth and without active influence of tectonic stresses. The vertical component of elastic deformations is calculated by the thermodynamic method on an absolute value and is less than horizontal one. It is confirmed experimentally by more than 30 thousand direct measurements with an unloading method in various parts of the globe [32-34].

An angle $\theta$ between the main normal stress and horizontal plane and an angle $\psi$ are the same, but with the vertical plane show the direction of action of the maximum normal and minimum tangent stresses for the un-

Table 4

Components of potential stresses in the undisturbed rock massif of the Ukrainian Crystalline Shield

\begin{tabular}{|c|c|c|c|c|c|c|}
\hline \multirow{2}{*}{$\begin{array}{c}\text { Depth, } \\
H, \mathrm{~m}\end{array}$} & \multirow{2}{*}{$\begin{array}{c}\text { Pressure, } \\
\sigma_{z}, \mathrm{MPa}\end{array}$} & \multicolumn{2}{|c|}{ Actual internal stresses, MPa } & Circle radius of & \multicolumn{2}{|c|}{ Elastic potential stresses, MPa } \\
\cline { 6 - 7 } & vertical, $\sigma_{z \phi}$ & horizontal, $\sigma_{x \phi}$ & $\begin{array}{c}\text { internal stresses, } \\
R_{i}, \mathrm{~m}\end{array}$ & $\begin{array}{c}\text { horizontal, } \\
\Delta \sigma_{x(y)}=\Delta \sigma_{y(y)}\end{array}$ & $\begin{array}{c}\text { vertical, } \\
\Delta \sigma_{z(y)}\end{array}$ \\
\hline 500 & 15.0 & 7.72 & 15.0 & 7.72 & 7.72 & 7.35 \\
\hline 1000 & 30.0 & 15.64 & 30.0 & 15.64 & 15.64 & 14.33 \\
\hline 1500 & 45.0 & 24.08 & 45.0 & 24.08 & 24.08 & 20.92 \\
\hline 2000 & 60.0 & 32.80 & 60.0 & 32.80 & 32.80 & 27.02 \\
\hline 2500 & 76.0 & 42.24 & 76.0 & 42.24 & 42.24 & 32.64 \\
\hline 3000 & 91.0 & 52.25 & 91.0 & 52.25 & 52.25 & 37.53 \\
\hline
\end{tabular}


disturbed massif of rocks. With the submit of vertical and horizontal loadings to the elementary volume of rock, the main normal stresses divide its area into mutually perpendicular subareas whose angles in the place of contact of tops are defined by values $2 \theta$ (Fig. 3,c).

The angle $\theta$ formed between the normal stress and the horizontal plane will be equal to, degree

$$
\theta=\frac{\pi}{2}-\psi,
$$

where $\psi$ is an angle between the main normal stress and the vertical plane, degree

$$
\psi=\operatorname{arctg} \lambda_{\text {el.o. }} .
$$

The angle $\psi$ is formed between the main normal stress acting in the massif of rocks and the vertical plane. The tg $\psi$ value is the relation of vertical loadings $\Delta \sigma_{z(y)}$ to horizontal ones $\Delta \sigma_{x(y)}$ and allows determining the main stresses acting in the undisturbed massif of rocks. Let us designate

$$
\operatorname{tg} \psi=\Delta \sigma_{z(y)} \Delta \sigma_{x(y)}^{-1}=\lambda,
$$

then, the main potential stresses will have a view of, $\mathrm{MPa}$

$$
\begin{gathered}
\sigma_{1(y)}=\Delta \sigma_{x(y)}(1+0.5 F) ; \\
\sigma_{2(y)}=\Delta \sigma_{x(y)}\left(\lambda_{k}-0.5 F\right) ; \\
\tau_{\max }=0.5\left(\sigma_{1(y)}-\sigma_{2(y)}\right) ; \\
F=(1-\lambda)\left(\frac{\sin 2 \psi}{\sin 2[0.5 \operatorname{arctg}(\sin 2 \psi)]^{-1}}\right) .
\end{gathered}
$$

Elastic stresses $\Delta \sigma_{z(y)}, \Delta \sigma_{x(y)}$ and $\Delta \sigma_{y(y)}$, connected with deformations are potential because work which they can do depends only on the size of the reversible deformation arising at partial or full removal of external loading [35-37].

The obtained square dependences of the main stresses operating in the undisturbed massif of rocks of Kryvorizskyi basin are represented in Fig. 3.

The relation of vertical potential stresses to horizontal is described by the coefficient of power zones shapes that decreases from 1 to 0 during reduction in rock strength from 200 to $40 \mathrm{MPa}$ and increasing in mining depth up to $5000 \mathrm{~m}$ on multiple exponential dependenc-

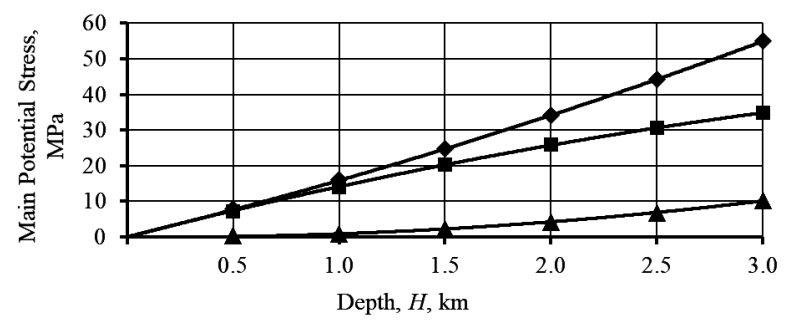

Stress: - normal, $\sigma_{1(y)} ; \boldsymbol{-}-$ normal, $\sigma_{2(y)} ; \mathbf{\wedge}-$ tangential, $\tau_{\text {мах }}$

Fig. 3. Dependences of changing of the main potential stresses acting in the undisturbed massif of rocks of Kryvorizskyi basin es. The mine working is epicenter of violation of energy balance in the massif that leads to formation of the safety capsule consisting of the system of ring energy zones in which on the sinusoidal fading autowave dependence an energy equilibration occurs. The amplitude of stresses decreases from mine working's contour to the capsule border, and the period of their action increases, which leads to destruction of rocks in near-the-contour zones (energy imbalance zones). Both and to increase in stresses in the zones (zones of balance of energy) closing the capsule in comparison with the undisturbed massif. In addition, values of elastic potential stresses in the undisturbed massif $\sigma_{1(y)}, \sigma_{2(y)}$ and $\tau_{\max }$, which perform work on deformation of rocks at violation of an initial equilibrium state, are used for modeling of stress fields around mine workings, stoping chambers and developed spaces, as well as during parameters calculations of structural elements of mining methods [38].

Testing the results. Results of modeling of the undisturbed massif for the settlement vertical profile located on the $92^{\text {nd }}$ surveying axis at a point of its crossing with the line of average strike $+1214 \mathrm{~m}$ at a depth of $1200 \mathrm{~m}$ of "Ternivska" mine, PJSC "Kryvorizskyi ZhRK" have shown that the volume mass of ore has increased by $0.79 \mathrm{MN} / \mathrm{m}^{3}$, and that of the containing rocks - by $0.22 \mathrm{MN} / \mathrm{m}^{3}$. In the conditions of volume compression, durability of ore has increased from 70 to $120.8 \mathrm{MPa}$, and that of rocks - from 180 to $350 \mathrm{MPa}$. Respectively, also absolute values of the module of Young for rocks have increased from $0.843 \cdot 10^{5}$ to $1.63 \cdot 10^{5}$, whereas for ores the increase is from $0.324 \cdot 10^{5}$ up to $0.593 \cdot 10^{5} \mathrm{MPa}$. The accuracy of the entropy method is confirmed by comparison of the calculated values with the values of temperature of rocks of Kryvorizskyi basin measured in prospecting wells at depths of 1400-2700 m which divergence that does not exceed 7-9\%. Distinction of the values of elastic deformations of rocks measured by the method of unloading and calculated at depths up to $1200 \mathrm{~m}$ in fields of "Zhovtneva" and "Ternivska" mines of PJSC "Kryvorizskyi ZhRK” makes 3-5\%. Calculated and experimentally established density values of rocks under the pressure up to $1.5 \cdot 10^{3} \mathrm{MPa}$ differ among themselves on average by $1.32 \%$, and density of minerals - by $2.15 \%$. Values of relative volume deformation of minerals with a pressure up to $4 \cdot 10^{3} \mathrm{MPa}$ were compared with experimental data for conditions of high pressure, and the divergence has not exceeded 7.9$10.6 \%$, while the measured and calculated speeds of distribution of longitudinal elastic waves in the rock massif, undisturbed by mining operations differed by 6-8\% [39-42].

\section{Conclusions.}

1. The analysis of methods for determination of rock strength has allowed expanding classification of methods of a research due to introduction of the synergetic group. This group includes entropy, thermodynamic and energy methods that allow investigating processes of power exchange in rocks and natural transformations of one type of energy to others. Improvement of the existing entropy method as a part of the thermodynamic theory and creation of new, energetic, one have allowed 
investigating the phenomenon of zonal structuring of the massif around mine workings and establishing exact quantity, the sizes and shape of energy zones as well as revealing sinusoidal-and-fading stresses and ring areas of deformation.

2. Distribution of entropy in the undisturbed massif rocks of the Ukrainian Crystalline Shield proceeds in mutually perpendicular directions corresponding to vertical and horizontal power flows. On sedate dependences in the massif only a part of potential energy, whose volume is 50 for the horizontal stresses, and $45 \%$ for for vertical ones from the difference of external loadings, is redistributed. The increase in potential energy in the massif of rocks of Kryvorizskyi basin at depths up to $3000 \mathrm{~m}$ leads to redistribution on sedate dependences for horizontal stresses already $95 \%$, and for vertical ones is $57 \%$ from the difference of external pressure.

\section{References.}

1. Khomenko, O., Sudakov, A., Malanchuk, Z., \& Malanchuk, Ye. (2017). Principles of rock pressure energy usage during underground mining of deposits. Naukovyi Visnyk Natsionalnoho Hirnychoho Universytetu, 2(158), 35-43.

2. Ilin, S. R., Samusya, V. I., Kolosov, D. L., Ilina, I. S., \& Ilina, S. S. (2018). Risk-forming dynamic processes in units of mine hoists of vertical shafts. Naukovyi Visnyk Natsionalnoho Hirnychoho Universytetu, 5(167), 64-71. DOI: $10.29202 /$ nvngu/2018-5/10.

3. Belmas, I., \& Kolosov, D. (2011). The stress-strain state of the stepped rubber-rope cable in bobbin of winding. Technical and Geoinformational Systems in Mining: School of Underground Mining 2011, 211-214.

4. Hrinov, V., \& Khorolskyi, A. (2018). Improving the process of coal extraction based on the parameter optimization of mining equipment. E3S Web Of Conferences, 60, 00017. DOI: 10.1051/e3sconf/20186000017.

5. Bondarenko, V.I., Kharin, Ye.N., Antoshchenko, N. I., \& Gasyuk, R. L. (2013). Basic scientific positions of forecast of the dynamics of methane release when mining the gas bearing coal seams. Naukovyi Visnyk Natsionalnoho Hirnychoho Universytetu, 5(137), 24-30.

6. Gornostayev, S., Walker, R., Hanski, E., \& Popovchenko, S. (2004). Evidence for the emplacement of ca. 3.0 Ga mantle-derived mafic-ultramafic bodies in the Ukrainian Shield. Precambrian Research, 132(4), 349362. DOI: 10.1016/j.precamres.2004.03.004.

7. Babets, D. V., Sdvyzhkova, O.O., Larionov, M. H., \& Tereshchuk, R. M. (2017). Estimation of rock mass stability based on probability approach and rating systems. Naukovyi Visnyk Natsionalnoho Hirnychoho Universytetu, 2(158), 58-64.

8. Physical Sciences. (1976). Science News, 109(17), 267. DOI: $10.2307 / 3960928$.

9. Gzovskiy, M. V., Turchaninov, I.A., Markov, G.A., \& Batugin, S.A. (1973). Napryazhennoe so-stoyanie zemnoy kory po dannym izmereniy v gornykh vyrabotkakh i tektonofizicheskogo analiza. In Napryazhennoe sostoyanie zemnoy kory (p. 50).

10. Dreus, A. Yu., \& Lysenko, K. Ye. (2016). Computer simulation of fluid mechanics and heat transfer process- es at the working face of borehole. Naukovyi Visnyk Natsionalnoho Hirnychoho Universytetu, 5(155), 29-35.

11. Khomenko, O., Kononenko, M., \& Bilegsaikhan, J. (2018). Classification of Theories about Rock Pressure. Solid State Phenomena, 277, 157-167. DOI: 10.4028/ www.scientific.net/ssp.277.157.

12. Prigozhin, I. (2001). Vvedenie v termodinamiku neobratimykh protsessov.

13. Khomenko, O. (2012). Implementation of energy method in study of zonal disintegration of rocks. Naukovyi Visnyk Natsionalnoho Hirnychoho Universytetu, 4(130), 44-54.

14. Lavrinenko, V.F., \& Lysak, V.I. (1977). Metod opredeleniya nachal'nogo napryazhennogo sostoyaniya massivov skal'nykh gornykh porod. Razrabotka rudnykh mestorozhdeniy, (24), 16-20.

15. Khomenko, O., \& Maltsev, D. (2013). Laboratory research of influence of face area dimensions on the state of uranium ore layers being broken. Naukovyi Visnyk Natsionalnoho Hirnychoho Universytetu, 2(134), 3137.

16. Bazarov, I. P. (1983). Termodinamika.

17. Khomenko, O., \& Rudakov, D. (2010). The first Ukrainian corporative university. New Techniques And Technologies In Mining, 203-206. DOI: 10.1201/b1132934.

18. Kovalenko, A. D. (1970). Osnovy termouprugosti.

19. Khomenko, O., Kononenko, M., \& Petlovanyi, M. (2015). Analytical modeling of the backfill massif deformations around the chamber with mining depth increase. New Developments In Mining Engineering 2015, 265-269. DOI: 10.1201/b19901-47.

20. Glensdorf, P., \& Prigozhin, I. (1973). Termodinamicheskaya teoriya struktury, ustoychivosti i fluktuatsii.

21. Dortman, N. B. (1976). Fizicheskie svoystva gornykh porod i poleznykh iskopaemykh: spravochnik geofizika. 22. Khomenko, O., Kononenko, M., \& Myronova, I. (2013). Blasting works technology to decrease an emission of harmful matters into the mine atmosphere. Mining $O f$ Mineral Deposits, 231-235. DOI: 10.1201/b16354-43.

23. Kozhevnykov, A., Dreus, A., Baochang, L., \& Sudakov, A. (2018). Drilling fluid circulation rate influence on the contact temperature during borehole drilling. Naukovyi Visnyk Natsionalnoho Hirnychoho Universytetu, 1(163), 35-42. DOI: 10.29202/nvngu/2018-1/14.

24. Khomenko, O., \& Barna, T. (2019). Zonal-andWave Structure of Open Systems on Micro, Mega- and Macrolevels of the Universe. Philosophy And Cosmology, 22, 24-32. DOI: 10.29202/phil-cosm/22/3.

25. Prigogine, I. (1947). Etude thermodynamique des phenomenes irréversibles.

26. Sudakov, A., Dreus, A., Khomenko, O., \& Sudakova, D. (2017). Analytical study of heat transfer in absorptive horizons of borehole at forming cryogenic protecting of the plugging material. Naukovyi Visnyk Natsionalnoho Hirnychoho Universytetu, 3(159), 38-42.

27. Shashenko, O.M., Sdvyzhkova, O.O., \& Babets, D. V. (2010). Method of argument group account in geomechanical calculation. In $12^{\text {th }}$ International Symposium on Environmental Issues and Waste Management 
in Energy and Mineral Production SWEMP 2010, (pp. 488-493).

28. Sdvizhkova, Ye.A., Babets, D. V., \& Smirnov, A. V. (2014). Support loading of assembly chamber in terms of Western Donbas plough longwall. Naukovyi Visnyk Natsionalnoho Hirnychoho Universytetu, 5(143), 26-32.

29. Sudakov, A., Khomenko, O., Isakova, M., \& Sudakova, D. (2016). Concept of numerical experimentof isolation of absorptive horizons by thermoplastic materials. Naukovyi Visnyk Natsionalnoho Hirnychoho Universytetu, 5(155), 12-16.

30. Sdvyzhkova, O.O., Babets, D.V., Kravchenko, K. V., \& Smirnov, A. V. (2016). Determining the displacements of rock mass nearby the dismantling chamber under effect of plow longwall. Naukovyi Visnyk Natsionalnoho Hirnychoho Universytetu, 2(152), 34-42.

31. Khomenko, O., Kononenko, M., \& Petlyovanyy, M. (2014). Investigation of stress-strain state of rock massif around the secondary chambers. Progressive Technologies Of Coal, Coalbed Methane, And Ores Mining, 241245. DOI: 10.1201/b17547-43.

32. Khomenko, O., Kononenko, M., \& Myronova, I. (2017). Ecological and technological aspects of iron-ore underground mining. Mining Of Mineral Deposits, 11(2), 59-67. DOI: 10.15407/mining11.02.059.

33. Obert, L. (1962). In situ determination of stress in rock. Mining Engineering, 14(8), 51-58.

34. Zhanchiv, B., Rudakov, D., Khomenko, O., \& Tsendzhav, L. (2013). Substantiation of mining parameters of Mongolia uranium deposits. Naukovyi Visnyk Natsionalnoho Hirnychoho Universytetu, 4(136), 10-18. 35. Stupnik, M., Kalinichenko, V., Pysmennyi, S., Fedko, M., \& Kalinichenko, O. (2016). Method of simulating rock mass stability in laboratory conditions using equivalent materials. Mining Of Mineral Deposits, 10(3), 46-51. DOI: 10.15407/mining10.03.046.

36. Khomenko, O., Tsendjav, L., Kononenko, M., \& Janchiv, B. (2017). Nuclear-and-fuel power industry of Ukraine: production, science, education. Mining Of Mineral Deposits, 11(4), 86-95. DOI: 10.15407/mining11.04.086.

37. Pivnyak, G., Dychkovskyi, R., Smirnov, A., \& Cherednichenko, Y. (2013). Some aspects on the software simulation implementation in thin coal seams mining. Energy Efficiency Improvement Of Geotechnical Systems, 1-10. DOI: 10.1201/b16355-2.

38. Stupnik, N. I., Fedko, M. B., Pismenniy, S. V., \& Kolosov, V.A. (2014). Development of recommendations for choosing excavation support types and junctions for uranium mines of state-owned enterprise skhidhzk. Naukovyi Visnyk Natsionalnoho Hirnychoho Universytetu, 5(143), 21-25.

39. Myronova, I. (2015). The level of atmospheric pollution around the iron-ore mine. New Developments In Mining Engineering 2015, 193-197. DOI: 10.1201/ b19901-35.

40. Khomenko, O., Kononenko, M., Myronova, I., \& Sudakov, A. (2018). Increasing ecological safety during underground mining of iron-ore deposits. Naukovyi Visnyk Natsionalnoho Hirnychoho Universytetu, 2(164), 2938. DOI: $10.29202 /$ nvngu/2018-2/3.
41. Mironova, I., \& Borysovs'ka, O. (2014). Defining the parameters of the atmospheric air for iron ore mines. Progressive Technologies Of Coal, Coalbed Methane, And Ores Mining, 333-339. DOI: 10.1201/b1754757.

42. Lozynskyi, V., Saik, P., Petlovanyi, M., Sai, K., \& Malanchuk, Y. (2018). Analytical Research of the Stress-Deformed State in the Rock Massif around Faulting. International Journal Of Engineering Research In Africa, 35, 77-88. DOI: 10.4028/www.scientific.net/ jera.35.77.

\section{Геоенергетика Українського кристалічного щита}

\section{О. С. Хоменко, М. М. Кононенко}

Національний технічний університет „Дніпровська політехніка“, м. Дніпро, Україна, e-mail: rudana.in.ua@ gmail.com

Мета. Розробити аналітичний метод, що дозволяє досліджувати енергетичний стан гірських порід у межах Українського кристалічного щита.

Методика. Аналітичні дослідження енергетичного стану гірських порід виконувалися за допомогою нового методу дослідження - ентропійного. Дослідження процесів перерозподілу потенційної енергії в масиві гірських порід проводилося за аналогією з відкритою термодинамічною системою. Запропонований методологічний підхід дозволив дослідити процеси енергетичного обміну в гірських породах і закономірні перетворення одних видів енергії в інші.

Результати. Проведено аналіз і виконана систематизація геодинамічних умов при підземній розробці рудних родовищ України. Показані шляхи розвитку нових гіпотез, теорій і методів дослідження енергетичного стану гірських порід. Розкрита проблематика опису у світовій практиці природнього стану гірських порід. Визначені компоненти перерозподілу енергії в масиві гірських порід: ентропії, потенціальних напружень і кутів їх дії. Проведена перевірка отриманих результатів на збіжність і зроблені відповідні висновки щодо їх застосування.

Наукова новизна. Термодинамічний баланс у гірських породах Українського кристалічного щита формується за рахунок урівноваження вертикальних і горизонтальних енергетичних потоків, що при збільшенні глибини розробки підвищують за степеневою залежністю компоненти тензора напружень, відхиляючи їх від гідростатичних.

Практична значимість. Розроблено ентропійний метод дослідження, що дозволяє дослідити природній стан гірських порід зі збільшенням глибини. Удосконалена класифікація методів дослідження напружено-деформованого стану гірських порід за рахунок уведення синергетичної групи, що включає ентропійний, термодинамічний та енергетичний методи. Встановлено, що поширення ентропії в гірських породах Українського кристалічного 
щита протікає у взаємно перпендикулярних напрямках, які відповідають вертикальним і горизонтальним енергетичним потокам.

Ключові слова: масив порід, гірський тиск, підземна розробка, геодинамічні явища, енергетичний стан, синергетичні методи, потенційні напруження, зворотні деформації

\section{Геоэнергетика Украинского кристаллического щита}

\section{О. Е. Хоменко, М. Н. Кононенко}

Национальный технический университет „Днепровская политехника“", г. Днепр, Украина, e-mail: rudana.in.ua@ gmail.com

Цель. Разработать аналитический метод, который позволяет исследовать энергетическое состояние горных пород в пределах Украинского кристаллического щита.

Методика. Аналитические исследования энергетического состояния горных пород выполнялось с помощью нового метода исследования - энтропийного. Исследование процессов перераспределения потенциальной энергии в массиве горных пород проводилось по аналогии с открытой термодинамической системой. Принятый методологический подход позволил исследовать процессы энергетического обмена в горных породах и закономерные преобразования одних видов энергии в другие.

Результаты. Проведен анализ и выполнена систематизация геодинамических условий при подземной разработке рудных месторождений Украины. Показаны пути развития новых гипотез, теорий и методов исследования энергетического состояния горных пород. Раскрыта проблематика описания в мировой практике природного состояния горных пород. Определены компоненты перераспределения энергии в массиве горных пород: энтропии, потенциальных напряжений и углов их действия. Проведена проверка полученных результатов на сходимость и сделаны соответствующие выводы по их применению.

Научная новизна. Термодинамический баланс в горных породах Украинского кристаллического щита формируется за счет уравновешивания вертикальных и горизонтальных энергетических потоков, которые при увеличении глубины разработки повышают по степенной зависимости компоненты тензора напряжений, отклоняя их от гидростатических.

Практическая значимость. Разработан энтропийный метод исследования, который позволяет исследовать естественное состояние горных пород с увеличением глубины. Усовершенствована классификация методов исследования напряженно-деформированного состояния горных пород за счет введения синергетической группы, которая включает энтропийный, термодинамический и энергетический методы. Установлено, что распространение энтропии в горных породах украинского кристаллического щита протекает во взаимно перпендикулярных направлениях, которые соответствуют вертикальным и горизонтальным энергетическим потокам.

Ключевые слова: массив пород, горное давление, подземная разработка, геодинамические явления, энергетическое состояние, синергетические методы, потенциальные напряжения, обратимые деформации

Рекомендовано до публікації докт. техн. наук I.А.Ковалевською. Дата надходження рукопису 25.02.18. 